\title{
Effect of inulin and oligofructose on the physicochemical, microbiological and sensory characteristics of symbiotic dairy beverages
}

\section{Efeito da inulina e da oligofrutose nas características físico- químicas, microbiológicas e sensoriais de bebidas lácteas simbióticas}

\author{
Anderson Rodrigo Fornelli1; Nataly Simões Bandiera ${ }^{2}$; \\ Marcela de Rezende Costa ${ }^{3}$; Cínthia Hoch Batista de Souza ${ }^{4}$; \\ Elsa Helena Walter de Santana ${ }^{4}$; Kátia Sivieri5; Lina Casale Aragon-Alegro ${ }^{4 *}$
}

\begin{abstract}
The aim of this study was to verify the effect of inulin and oligofructose on the physicochemical, microbiological and sensory characteristics of symbiotic dairy beverages. Four formulations were made: 1) a control (C); 2) a sample with added Lactobacillus paracasei (P); 3) a sample with added L. paracasei and inulin (PI); and 4) a sample with added L. paracasei and oligofructose (PO). The probiotic population, $\mathrm{pH}$, and acidity of the products were evaluated once a week for 21 days while refrigerated $\left(5 \pm 1^{\circ} \mathrm{C}\right)$. Possible contaminating microorganisms (coliforms, E. coli, and Salmonella spp.) were investigated after three days of storage. Sensorial acceptance and purchase intention were evaluated seven days after manufacture. Dairy beverages presented with L. paracasei populations above $8.50 \log \mathrm{CFU} / \mathrm{mL}$ during the whole storage period. Significantly $(\mathrm{p}<0.05)$ lower $\mathrm{pH}$ values were observed in P and PI, and higher acidity values were found in all formulations throughout storage. The dairy beverages were considered to be a promising matrix for the probiotic microorganism L. paracasei. The prebiotic additions (inulin and oligofructose) did not interfere with the overall acceptance and intention to purchase the beverages.
\end{abstract}

Key words: Whey, Lactobacillus paracasei, prebiotics, probiotics, shelf life

\section{Resumo}

O objetivo deste estudo foi verificar o efeito da inulina e da oligofrutose nas características físico-químicas, microbiológicas e sensoriais de bebidas lácteas simbióticas. Foram desenvolvidas quatro formulações de bebidas: controle (C), com adição de Lactobacillus paracasei (P), com adição de L. paracasei e inulina (PI) e com adição de $L$. paracasei e oligofrutose (PO). As populações do micro-organismo probiótico, o $\mathrm{pH}$ e a acidez dos produtos foram avaliados semanalmente, durante armazenamento refrigerado $\left(5 \pm 1^{\circ} \mathrm{C}\right)$ por 21 dias. A pesquisa de possíveis micro-organismos contaminantes (coliformes, E. coli e Salmonella

\footnotetext{
${ }^{1}$ Discente do Curso de Graduação em Química, Universidade do Norte do Paraná, UNOPAR, Londrina, PR, Brasil. E-mail: andersonfornelli@hotmail.com

${ }^{2}$ Discente do Curso de Mestrado em Ciência e Tecnologia do Leite e Derivados, UNOPAR, Londrina, PR, Brasil. E-mail: natalybandiera@gmail.com

${ }^{3}$ Prof $^{\mathrm{a}}$, Faculdade de Medicina Veterinária e Zootecnia. Universidade Federal de Mato Grosso de Sul, UFMS, Campo Grande, MS, Brasil. E-mail: marcela.rezende@ufms.br

${ }^{4}$ Profs. do Mestrado em Ciência e Tecnologia de Leite e Derivados, UNOPAR, Londrina, PR, Brasil. E-mail: cinthiahoch@yahoo. com.br; elsahws@hotmail.com; lcalegro@yahoo.com.br

5 Pesquisadora, Faculdade de Ciências Farmacêuticas. Universidade Estadual Paulista, UNESP, Jaú, SP, Brasil. E-mail: katia@ tiabrasil.com.br

* Author for correspondence
} 
spp.) foi realizada após três dias de refrigeração. A aceitabilidade sensorial e a intenção de compra foram avaliadas sete dias após a produção. As populações observadas para o micro-organismo probiótico $L$. paracasei foram superiores a $8,50 \log \mathrm{UFC} / \mathrm{mL}$ durante toda a vida de prateleira dos produtos. Houve redução significativa nos valores de $\mathrm{pH}$ para $\mathrm{P}$ e PI e aumento significativo na acidez para todas as formulações $(\mathrm{p}<0,05)$ ao longo do armazenamento. As bebidas lácteas apresentaram-se como uma matriz promissora para veiculação de L. paracasei. A adição dos ingredientes prebióticos (inulina e oligofrutose) às bebidas lácteas não interferiram na viabilidade de $L$. paracasei e na aceitabilidade global e na intenção de compras das bebidas.

Palavras-chave: Soro de leite, Lactobacillus paracasei, prebióticos, probióticos, vida-de-prateleira

\section{Introduction}

Milk beverage production is a primary option for the rational use of cheese whey due to its excellent nutritional value (ÖZER; KIRMACI, 2010). Several authors have investigated options for new uses of this byproduct, especially with the development of dairy beverages (CASTRO et al., 2013a; CASTRO et al., 2013b; MAITY; KUMAR; MISRA, 2008; PAVUNC et al., 2009). Whereas the biological oxygen demand of whey is high, it is possible to prevent environmental pollution caused by improper disposal of cheese whey (ALMEIDA; BONASSI; ROÇA, 2001).

Whey-based products allow manufacturers to reduce the cost of ingredients in addition to the advantage of having a concentrated source of nutrients, particularly proteins of high nutritional value and calcium (HUGUNIN, 1999).

According to the Technical Rules of Identity and Quality of Dairy Beverages, a dairy beverage is the milk product resulting from milk (fresh, pasteurized, sterilized, UHT, reconstituted concentrate, powder, whole, semi-skimmed, and skimmed) and whey (liquid, concentrate, and powder) and may or may not contain other substances, such as food ingredients, vegetable fat, fermented milk, lactic cultures, and other dairy products. The milk base must be at least $51 \%(\mathrm{w} / \mathrm{w})$ of the total ingredients of the product (BRASIL, 2004).

In addition to whey, milk, and lactic bacteria, dairy beverages contain other ingredients in their formulation, such as acidulants, flavoring agents, acidity regulators, stabilizers, thickeners, emulsifiers, colorants, preservatives, pulp, fruit pieces or juices and honey (THAMER; PENNA, 2006). In this context, the development of a functional dairy beverage fermented by probiotics and with added prebiotics is a viable alternative to the use of whey without the need for major investments or changes in routine manufacturing (THAMER; PENNA, 2005).

Probiotics are live microorganisms that, when administered in adequate amounts, confer a health benefit to the host (FAO, 2001; SANDERS, 2003). These microorganisms confer several beneficial health effects, including the activation of immune mechanisms, antagonism of the growth of pathogenic organisms, improved macrophage production, stimulation of suppressor cells, stimulation of intestinal motility with consequent constipation relief, anticarcinogenic activity, synthesis of B vitamins, stabilization of the intestinal flora after antibiotic use, restoration of intestinal permeability with effects on mucin gene expression (essential for mucus production in the intestine), improved absorption of certain nutrients, and hypocholesterolemic action (GOMES; MALCATA, 1999; KOMATSU; BURITI; SAAD, 2008; OLIVEIRA et al., 2002; SIVIERI; OLIVEIRA, 2002). Among the probiotic strains, Lactobacillus paracasei has been extensively studied with respect to its probiotic properties and is commonly used as a probiotic in dairy products (BURITI et al., 2007).

However, to exert their beneficial effects, probiotics should remain viable during the entire shelf life of the product (ROY, 2005). Gomes and Malcata (1999) emphasized that manufacturers must 
ensure the minimum number of viable cells in the product at the time of consumption. The minimum daily dose of probiotic therapy is considered $10^{8}-10^{9}$ CFU (ANVISA, 2005), which corresponds to the consumption of $100 \mathrm{~g}$ or $\mathrm{mL}$ of product containing $10^{6}$ to $10^{7} \mathrm{UFC} / \mathrm{g}$ or $\mathrm{mL}$.

Prebiotics are defined as selectively fermentable ingredients that allow specific changes in the composition and / or activity of beneficial intestinal microflora, resulting in benefits to the welfare and health of the host (ROBERFROID, 2007; WANG, 2009). These components act more frequently in the colon, although they may have some impact on the microorganisms of the small intestine (GIBSON; ROBERFROID, 1995; HAULY; MOSCATTO, 2002; ROBERFROID, 2001). Prebiotics in food include oligosaccharides, galacto-oligosaccharides (GOS), fructo-oligosaccharides (FOS), lactulose and inulin, among others. Oligosaccharides, as well as inulin, are prebiotics that have been widely studied and well-characterized (HOLZAPFEL; SCHILLINGER， 2002; KOLIDA; TUOHY; GIBSON, 2002). Among the benefits of prebiotic intake is the increased populations of bifidobacteria in the colon, which have an antagonistic effect on the activity of putrefactive bacteria. Moreover, fermentation of prebiotics by bifidobacteria decreases the $\mathrm{pH}$ of the colon, which favors the absorption of certain minerals, such as calcium, magnesium and iron, and shows some cancer prevention effects (SCHOLZ-AHRENS et al., 2007; THAMMARUTWASIK et al., 2009).

When prebiotics are combined with probiotics, their relationship is classified as symbiotic (HOLZAPFEL; SCHILLINGER, 2002).
The aim of this study was to develop dairy beverages with added probiotic Lactobacillus paracasei and prebiotic ingredients (inulin or oligofructose) and to assess the behavior of the culture and the characteristics of the beverage based on the prebiotics used in the formulation.

\section{Materials and Methods}

\section{Production of dairy beverages}

Four dairy beverage formulations were produced and are shown in Table 1: control - without the addition of L. paracasei (C); containing L. paracasei (P); containing L. paracasei and inulin (PI); and containing L. paracasei and oligofructose (PO).

First, $106.5 \mathrm{~g}$ of skimmed milk (Polly, Confepar, Londrina, Brasil) was dissolved in $1 \mathrm{~L}$ of pre-heated water at $90{ }^{\circ} \mathrm{C}$ for $10 \mathrm{~s}$. The reconstituted milk was cooled in an ice water bath until it reached $42{ }^{\circ} \mathrm{C}$, which was before the addition of lactic culture (Streptococcus thermophilus e Lactobacillus bulgaricus - YO-MIX ${ }^{\mathrm{TM}}$ 496, 100 DCU, Danisco, Dangé, France). In addition to the traditional yogurt culture (YO-MIX ${ }^{\mathrm{TM}}$ 496, Danisco), the probiotic culture Lactobacillus paracasei (Lpc$37^{\mathrm{TM}}, 50 \mathrm{DCU}$, Danisco) was added to formulations P, PI, and PO. Inulin (Beneo GR, Orafti, Oreye, Bélgica) was added to the PI formulation, and oligofructose (Beneo P95, Orafti, Oreye, Bélgica) was added to the PO formulation. The direct vat set (DVS) cultures were added directly to milk under aseptic conditions, both at a concentration of $2 \%$. The samples were incubated at $42{ }^{\circ} \mathrm{C}$, and the fermentation time was measured from the time of inoculation until the product reached a $\mathrm{pH}$ of 4.7 to 4.8. After fermentation, the products were stored at $5 \pm 1{ }^{\circ} \mathrm{C}$ for 24 hours. Then, the gel was broken by manual shaking for 30 seconds using a spatula. 
Table 1. Formulations of dairy beverages: C (without addition of L. paracasei), P (containing L. paracasei), PI (containing L. paracasei and inulin) and PO (containing L. paracasei and oligofructose).

\begin{tabular}{lcccc}
\hline Ingredients (\%) & C & P & PI & PO \\
\hline Water & 71.0 & 71.0 & 71.0 & 71.0 \\
Skimmed milk & 7.55 & 7.55 & 7.55 & 7.55 \\
Whey powder & 5.00 & 5.00 & 5.00 & 5.00 \\
Sugar & 12.0 & 12.0 & 10.0 & 10.0 \\
Pulp & 2.00 & 2.00 & 2.00 & 2.00 \\
Aroma & 0.05 & 0.05 & 0.05 & 0.05 \\
Stabilizer & 0.40 & 0.40 & 0.40 & 0.40 \\
Yogurt culture & 2.00 & 2.00 & 2.00 & 2.00 \\
Probiotic culture & $(-)$ & $(+)$ & $(+)$ & $(+)$ \\
Inulin & $(-)$ & $(-)$ & 2.00 & $(-)$ \\
Oligofructose & $(-)$ & $(-)$ & $(-)$ & 2.00 \\
\hline
\end{tabular}

(+): Present; (-): Absent.

Source: Elaboration of the authors.

After breaking the gel, the following ingredients were added: whey powder (Confepar, Londrina, Brazil), strawberry pulp (PolpaNorte, Japurá, Brasil), strawberry aroma (All Flavors, Diadema, Brasil), sugar ((União, Coopersucar União, Limeira, Brasil), and the stabilizer LBG (Danisco, Cotia, Brasil) in the quantities described in Table 1. All ingredients were mixed by mechanical stirring for one minute using a blender (Walita, Varginha, Brasil). Dairy beverages were packaged in plastic bottles $(500 \mathrm{~mL})$ and stored in a refrigerator at $5 \pm$ $1^{\circ} \mathrm{C}$ for 21 days.

Samples P, PI, and PO (containing L. paracasei) were analyzed immediately after their production for initial microorganism populations according to the methodology described below. All samples were classified as probiotic beverages once the initial $L$. paracasei populations reached $9.50 \log \mathrm{CFU} / \mathrm{mL}$.

\section{Characterization of dairy beverages}

Population of Lactobacillus paracasei and contaminating microorganisms

For the enumeration of $L$. paracasei, total coliforms, and $E$. coli in the beverages containing probiotics, $25 \mathrm{~mL}$ of portions of milk beverage were homogenized with $225 \mathrm{~mL}$ of $0.1 \%$ peptone water in a Bag Mixer (Interscience, St Nom, France). Subsequent decimal dilutions were carried out using the same diluent.

For enumeration of Lactobacillus paracasei, 1-mL aliquots of each dilution were transferred to sterile Petri plates. Then, agar DeMan-RogosaSharpe - MRS (Himedia, Mumbai, India) acidified (pH 5.4) with glacial acetic acid was added. The plates were incubated under anaerobic conditions at $37^{\circ} \mathrm{C}$ for 48 hours.

For the enumeration of total coliforms and Escherichia coli, 1-mL aliquots of each dilution were transferred to Petrifilm ${ }^{\mathrm{TM}}$ EC plates (3M Microbiology, St. Paul, MN, EUA) and incubated at $37^{\circ} \mathrm{C}$ for 24 and 48 hours for measuring total coliforms and E. coli, respectively.

For the enumeration of Salmonella spp., 25-mL aliquots of milk beverage samples were homogenized with $225 \mathrm{~mL}$ of lactose-broth (Himedia) and incubated at $35^{\circ} \mathrm{C}$ for 24 hours. Then, aliquots of 0.1 $\mathrm{mL}$ and $1 \mathrm{~mL}$ of lactose broth were transferred to 10 $\mathrm{mL}$ of Rappaport-Vassiliadis broth (Himedia) and 10 $\mathrm{mL}$ of tetrathionate broth (Himedia), respectively. The first was incubated at $42{ }^{\circ} \mathrm{C}$ and the latter at 35 ${ }^{\circ} \mathrm{C}$. After 24 hours of incubation, both broths were seeded separately in Petri plates containing sterile 
Hektoen Enteric agar (Himedia) and SalmonellaShigella agar (Himedia) and were subsequently incubated at $35{ }^{\circ} \mathrm{C}$ for 24 hours. Upon appearance of colonies with characteristics of Salmonella spp., they were inoculated into lysine iron agar (LIA Oxoid) and triple sugar iron agar (TSI, Oxoid) and incubated at $35^{\circ} \mathrm{C}$ for 24 hours. The typical colonies were subjected to other biochemical tests (Enterokit - EPM, Mili and citrate, Probac do Brasil Produtos Bacteriológicos Ltda, São Paulo, Brasil) and slide agglutination with polyvalent serum antiSalmonella (Probac do Brasil) (ANDREWS et al., 2001).

Enumeration of L. paracasei from the samples containing probiotics was performed after 1, 7, 14 and 21 days of refrigerated storage. Contaminating microorganism populations were enumerated after 3 days of storage at $5 \pm 1{ }^{\circ} \mathrm{C}$. The results were expressed as colony forming units $/ \mathrm{mL}(\mathrm{CFU} / \mathrm{mL})$.

\section{Physicochemical characterization of dairy beverages}

The physicochemical analyses were performed according to the AOAC methods (AOAC, 1995). The $\mathrm{pH}$ of the samples was determined using a digital potentiometer (TEC-2, Tecnal, Piracicaba, Brasil). The acidity was determined by the titration method. Analyses of $\mathrm{pH}$ and acidity were performed after 1, 7, 14, and 21 days of refrigerated storage. The moisture (total solids) of the samples was determined by the gravimetric method in a forced air circulation oven (Nova Etica, Vargem Grande Paulista, Brasil) at $100^{\circ} \mathrm{C}$. Lipids were determined by the Gerber method (INSTITUTO ADOLFO LUTZ, 2005). The protein content was determined by the Kjeldahl method using a conversion factor of 6.38. The ash content was determined by the method of incineration in a muffle (FDG, EDGCON 1P, São Paulo, Brasil) at $550{ }^{\circ} \mathrm{C}$. Carbohydrates were measured as the difference after subtracting the lipid, protein, and ash content of the total composition. The proximate analysis of dairy beverages was carried out after one day of refrigerated storage at $5 \pm 1{ }^{\circ} \mathrm{C}$.

\section{Sensory evaluation}

Sensory evaluation was performed in the sensory analysis laboratory after approval of the ethics committee (Protocol 0195/08). In total, 170 untrained assessors participated in the analyses among the students and staff of the university where the study was carried out. The overall acceptance and purchase intent of different dairy beverages were assessed, and the tests were conducted in two sessions (morning and afternoon).

Analyses of dairy beverages were performed after seven days of refrigerated storage at $5 \pm 1^{\circ}$ $\mathrm{C}$, and the samples were presented in a monadic form. The assessors were selected according to their typical consumption of milk-based beverages after indicating their availability and interest in participating in the test. Before starting the sensory evaluation, the participants signed and received a copy of the Statement of Consent, which provided all of the information about the analysis, product in question, as well as the inclusion and exclusion criteria for participation (no allergic reaction or intolerance to ingredients, aged between 18 and 60 years, regular consumers of milk beverages and probiotic and prebiotic foods, not having any chronic disease, and not be subjected to medical treatments). Participants were instructed to evaluate the characteristics of the product using a nine-point hedonic scale ranging from 1 (extremely dislike) to 9 (extremely like). For the purchase intent test, a structured five-point scale ranging from 1 (definitely not buy) to 5 (certainly buy) was used (MEILGAARD; CIVILLE; CARR, 1999).

\section{Experimental design and statistical analysis}

Analysis of variance (ANOVA) was used to compare the C, P, PI, and PO formulations with respect to their composition using PROC GLM 
in SAS 9.0 software (MONTGOMERY, 2000). For analysis of the enumeration of $L$. paracasei (formulations P, PI, and PO) and physicochemical determinations ( $\mathrm{pH}$ and titratable acidity), mixed effects models were used for analysis between groups and across days using PROC MIXED in SAS 9.0 software (SCHALL, 1991).

\section{Results and Discussion}

\section{Chemical composition of dairy beverages}

Table 2 presents the results of the proximate composition of the dairy beverages. No significant differences were observed for any samples $(\mathrm{p}>0.05)$. The fat content ranged from $2.62 \%$ (formulation $\mathrm{C}$ ) to $2.7 \%$ (formulations $\mathrm{P}$ and PI). According to these results, the milk beverages in the present study can be classified as partially skim dairy beverages because current Brazilian law has established this classification for products with a maximum of $2.9 \%$ fat (BRASIL, 2004).

The ash contents were close to $0.7 \%$ for all formulations. Similar results were observed by Yazici and Akgun (2004) in yogurts made from milk with 0.5 and $2.0 \%$ fat.

Table 2. Proximate composition (mean $\pm \mathrm{SD}$ ) of milk beverages: $\mathrm{C}$ (without $L$. paracasei), $\mathrm{P}$ (containing $L$. paracasei), PI (containing L. paracasei and inulin) and PO (containing L. paracasei and oligofructose) in the final product (wet matter) after 1 day of refrigerated storage at $5 \pm 1^{\circ} \mathrm{C}$.

\begin{tabular}{|c|c|c|c|c|}
\hline Components (\%)* & $\mathrm{C}$ & $\mathbf{P}$ & PI & PO \\
\hline Moisture & $84.82 \pm 2.03$ & $85.38 \pm 1.94$ & $84.96 \pm 2.68$ & $83.95 \pm 1.62$ \\
\hline Fat & $2.62 \pm 0.14$ & $2.70 \pm 0.11$ & $2.70 \pm 0.12$ & $2.63 \pm 0.12$ \\
\hline Ash & $0.76 \pm 0.06$ & $0.76 \pm 0.11$ & $0.74 \pm 0.08$ & $0.72 \pm 0.07$ \\
\hline Carbohydrates & $10.18 \pm 2.04$ & $9.49 \pm 2.14$ & $10.06 \pm 2.75$ & $11.36 \pm 1.57$ \\
\hline Protein & $1.61 \pm 0.24$ & $1.54 \pm 0.09$ & $1.54 \pm 0.11$ & $1.49 \pm 0.12$ \\
\hline
\end{tabular}

* No significant differences $(\mathrm{p}>0.05)$ in the proximate composition of the samples.

Source: Elaboration of the authors.

The protein content ranged from $1.49 \%$ (formulation $\mathrm{PO}$ ) to $1.61 \%$ (formulation $\mathrm{C}$ ). Cunha et al. (2008) studied the physicochemical characterization of probiotic milk beverages and found protein levels between 2.2 and 2.8\%. According to Brazilian law, the product must have at least $1.2 \mathrm{~g}$ protein / $100 \mathrm{~g}$ of product to be legally classified as a fermented milk beverage (BRASIL, 2004). All formulations in this study met these criteria once they had protein values higher than the minimum required.

The carbohydrate content ranged from 9.49\% (P formulation) to $11.36 \%$ (formulation PO). With respect to total solids, the values ranged from $14.62 \%$ (formulation D) to $16.05 \%$ (formulation PO). These results are in agreement with the literature, as Thamer and Penna (2006) found similar levels of total solids in prebiotic and probiotic beverages, varying from 15.68 to $18.97 \%$.

\section{Physicochemical characterization of milk beverages}

The titratable acidity determined in Dornic degrees varied from 89 (formulation $\mathrm{C}$, day 1) to 136 (formulation PI, day 21) (Figure 1).

The acidity of fermented dairy products is one of the factors that may limit product acceptance (THAMER; PENNA, 2006). According to Kessler (1981), the total acid in yogurt is approximately $58.9 \%$ lactic acid, $28.1 \%$ citric acid, $5.3 \%$ acetic acid, 2.4\% formic acid, and 2.3\% succinic acid. Lactic acid acts as a natural preservative, in 
addition to making the components of milk more digestible, favoring individuals with digestion problems (SILVA et al., 2001). Additionally, lactic acid leads to destabilization of the casein micelles and consequent gel formation, conferring a characteristically acidic flavor and improving flavor during yogurt production (KESSLER, 1981).

The refrigerated storage of dairy beverages can lead to increased acidity (THAMER; PENNA, 2006), which was observed in this study. During storage, all products showed significantly higher acidity values over time $(p<0.05)$. Similarly, Thamer and Penna (2006) evaluated the physicochemical behavior of fermented milk beverages containing probiotics and observed higher acidity values, on average $45^{\circ} \mathrm{D}$, during the shelf life of the products.

The acidity values found in this study were lower than those reported by Thamer and Penna (2006). According to Gurgel and Olive (1995), variations in the acidity of dairy beverages occur to a greater or lesser degree depending on the refrigeration temperature, storage time, and post-acidification power of the cultures. Therefore, the selection of cultures with low post-acidification power is an important factor in the quality of fermented products.

The $\mathrm{pH}$ of the various formulations ranged from 4.51 (formulation $\mathrm{P}$, day 21) to 4.90 (formulation C, day 7 and 21) (Figure 1). During refrigerated storage, statistically significant reductions $(\mathrm{p}<0.05)$ in $\mathrm{pH}$ were observed after 21 days of storage for the formulations containing the probiotic Lactobacillus paracasei (P, PI, PO). The control formulation (C) showed no significant reduction in $\mathrm{pH}(\mathrm{p}>0.05)$. However, there was a significant increase in the acidity values for the control sample, which was probably due to the presence of Streptococcus thermophilus that produces lactic acid and small concentrations of $\mathrm{CO}_{2}$ and formic acid from the fermentation of lactose resulting in increased acidity (FOX et al., 2000; ZISU; SHAH, 2003).

Figure 1. Titratable acidity and $\mathrm{pH}$ of dairy beverages: $\mathrm{C}$ (without addition of $L$. paracasei), $\mathrm{P}$ (containing $L$. paracasei), PI (containing L. paracasei and inulin) and PO (containing $L$. paracasei and oligofructose) after 1, 7, 14 , and 21 days of refrigerated storage at $5 \pm 1{ }^{\circ} \mathrm{C}$.
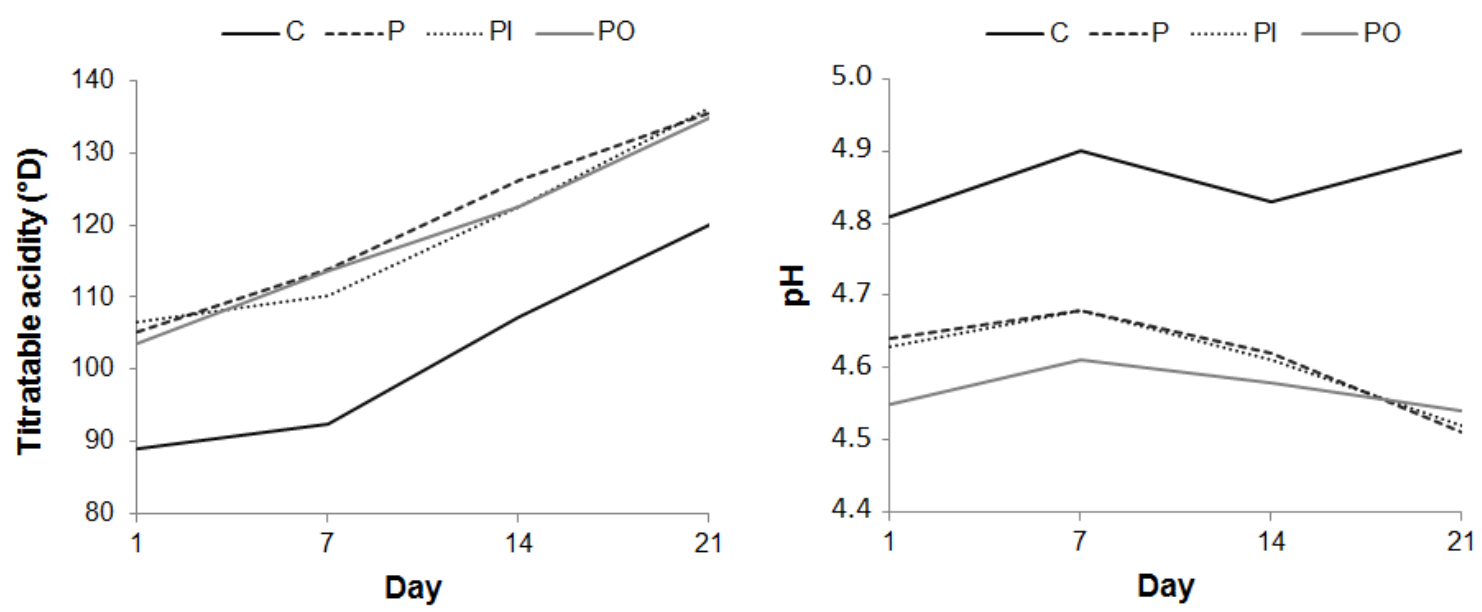

Source: Elaboration of the authors. 
According to Fox and McSweeney (1998), an important characteristic of milk is its high buffering capacity, which is a resistance to change in $\mathrm{pH}$ after addition of an acid or base. The main milk buffering compounds are salts (mainly calcium phosphate, citrate and bicarbonate) and amino acids.

The markedreduction in the $\mathrm{pHof}$ the formulations and the significant increase in acidity $(p<0.05)$ is due to the presence of the probiotic Lactobacillus paracasei and the Streptococcus thermophilus culture. The L. paracasei microorganism belongs to the group of homo fermentative lactobacilli that produce lactic acid as their major metabolite (CHAMPAGNE; GARDNER; ROY, 2005; HOLZAPFEL; SCHILLINGER, 2002).

Gurgel and Oliveira (1995) observed greater reductions in the $\mathrm{pH}$ (4.39 to 4.06$)$ of yogurts stored at higher temperatures, which led to a lower acceptance of the products. In the present study, the lower $\mathrm{pH}$ values observed were close to 4.5 after 21 days of storage for P, PI, and PO formulations and were higher than those reported by the authors mentioned above. Furthermore, these results did not affect the acceptance of the products, as discussed in the Sensory Evaluation section.

\section{Microbiological analyses}

With respect to contaminating microorganisms, Salmonella spp., total coliforms and E. coli were not found in any samples. The probiotic population is essential to test whether beverages met the requirements of Brazilian legislation. The $L$. paracasei counts ranged from 8.74 to $9.71 \log \mathrm{CFU}$ / $\mathrm{mL}$ (formulations PI and P, respectively) (Figure 2).

Some authors state that the minimum concentration of viable probiotic bacteria in a food at the time of purchase should be $10^{6} \mathrm{CFU} / \mathrm{g}$ or $\mathrm{mL}$ (SHAH et al., 1995) or $10^{7} \mathrm{CFU} / \mathrm{g}$ or mL (RYBKA; FLEET, 1997; VINDEROLA; REINHEIMER, 2000).

Figure 2. Lactobacillus paracasei $(\log \mathrm{CFU} / \mathrm{mL}$ ) in the milk beverages P (containing L. paracasei), PI (containing $L$. paracasei and inulin) and PO (containing $L$. paracasei and oligofructose) after 1, 7, 14, and 21 days of refrigerated storage at $5 \pm 1^{\circ} \mathrm{C}$.

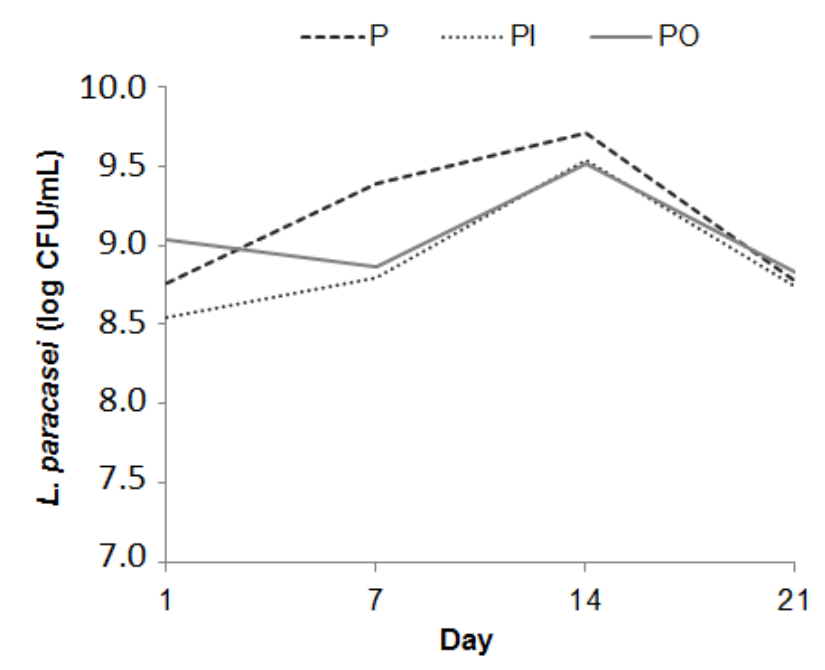

Source: Elaboration of the authors. 
The L. paracasei populations in this study were higher than $10^{6} \mathrm{CFU} / \mathrm{mL}$ throughout the refrigerated storage for all formulations (Figure 2). These results are in agreement with the literature. Several authors found probiotic populations of $10^{6} \mathrm{CFU} / \mathrm{mL}$ for fermented milks (AWAISHEH; HADDADIN; ROBINSON, 2005; PINTO et al., 2006), soy yogurt (EL-GAWAD et al., 2005), yogurt from sheep milk (BONCZAR; WSZOLEK; SIUTA, 2002), and yogurt from goat milk (FARNSWORTH et al., 2006; GÜLER-AKIN; AKIN, 2007).

In this paper, the $\mathrm{P}$ formulation showed a significant reduction in L. paracasei populations between the 14th and the 21st day of storage ( $p$ $<0.05$ ). In contrast, on day 21 , a probiotic count of $8.77 \log \mathrm{CFU} / \mathrm{mL}$ was observed. For P, PI, and PO formulations, although there was a significant increase in $L$. paracasei populations between the $7^{\text {th }}$ and $14^{\text {th }}$ day of refrigerated storage $(p<0.05)$, there was a decrease at the end of the storage period ( $p<0.05$ ). Despite this decrease, the probiotic populations at the end of the refrigerated storage were 8.77, 8.74, and $8.83 \log \mathrm{CFU} / \mathrm{mL}$ for P, PI and $\mathrm{PO}$, respectively, which is satisfactory for a probiotic food according to the criteria of current Brazilian legislation (ANVISA, 2005).

Similar results were observed by Drgalić, Tratnik and Bozanic (2005), who produced a beverage using reconstituted whey fermented with $L$. acidophilus La-5 and Bifidobacterium animalis Bb-12. The authors found probiotic populations of $10^{7} \mathrm{CFU} /$ $\mathrm{mL}$ across 28 days of refrigerated storage.

Thamer and Penna (2005) evaluated 12 formulations of dairy beverages containing Bifidobacterium spp. And Lactobacillus acidophilus. The authors found suitable probiotic populations in all formulations as the counts of both cultures were at least $10^{6} \mathrm{CFU} / \mathrm{mL}$ during the entire shelf life. Likewise, Krüger et al. (2008) found L. acidophilus and Bifidobacterium spp. Populations of $10^{6} \mathrm{CFU}$ $/ \mathrm{mL}$ in probiotic milk beverages after 22 days of storage.
Different dairy product formulations can act positively or negatively on the multiplication of probiotic microorganisms (THAMER; PENNA, 2005). In the present study, the addition of the prebiotics oligofructose (PO) and inulin (PI) to dairy beverages did not affect the viability of L. paracasei, as significant differences ( $p>0.05)$ were observed in these populations between formulations containing prebiotics (PI and PO) and the P formulation with L. paracasei only for all storage periods (Figure 2). Similarly, Pimentel, Garcia and Prudencio (2012a, $2012 \mathrm{~b}$ ) observed that the addition of inulin in yogurt containing $L$. paracasei did not influence these populations, which remained above $10^{7} \mathrm{CFU} / \mathrm{ml}$ during refrigerated storage.

Thamer and Penna (2005) studied the survival of probiotic microorganisms in fermented milk beverages and found that highly acidic products (e.g., yogurt) reduce the viability of probiotic microorganisms compared to products with low acidity (e.g., cheese), which makes it necessary to make a careful selection of strains to be used in each type of product.

\section{Sensory analysis}

Panelists who participated in the sensory evaluation were aged between 18 and 60 years, and 83 were male $(48.82 \%)$ and $87(51.18 \%)$ were female.

The mean scores assigned by the judges regarding the acceptance of the $\mathrm{C}, \mathrm{P}, \mathrm{PI}$, and PO formulations were $6.32,6.12,5.89$, and 5.66, respectively. Only milk beverages with $L$. paracase $i$ and oligofructose (PO) showed a statistically significant difference ( $p$ $<0.05)$ compared to the control. As seen in Figure 3 , the majority of the panelists assigned scores between 6 and 9 ( $6=$ like slightly, $9=$ extremely like) for dairy beverages. Similar values were observed by Sivieri and Oliveira (2002) in their sensory evaluation of dairy beverages containing fat substitutes. In this study, the addition of inulin did not influence the sensory acceptance of the beverage 
because no significant differences were observed between formulations PI and C. Similarly, Isik et al. (2011) observed that the addition of inulin did not affect the sensory acceptance of frozen yogurt.

According to the purchase intent results (Figure 3 ), the majority of the panelists would buy all of the beverages. The most frequent purchase intent scores were between 4 and 5 ( $4=$ possibly buy, 5 $=$ definitely would buy). The mean purchase intent was 3.51, 3.20, 3.10 and 3.07 for formulations C, P, PI and PO, respectively. Cruz et al. (2013) observed that people would not purchase yogurt supplemented with different oligofructose concentrations, probably due to changes in product characteristics.

The sensory evaluation period ( 7 days after manufacture) prevented the excessive acidity of the products at the end of their shelf life, which may have interfered with acceptance. Unsatisfactory results were observed by Krüger et al. (2008) in the sensory analysis of a probiotic milk beverage after 25 days of storage. According to the opinion of the panelists, the rejection of the product in this period may have occurred due to its highly acidic flavor.

Dairy beverages have proven to be a promising food for the propagation of the probiotic microorganism L. paracasei because the probiotic's population observed throughout the shelf life of the products was higher than $8.5 \log \mathrm{CFU} / \mathrm{mL}$. The addition of prebiotic ingredients (inulin and oligofructose) to dairy beverages did not affect the viability of $L$. paracasei because the populations found in these formulations did not differ statistically from the formulation produced without prebiotics added.

Figure 3. Frequency histograms of the overall acceptance (rejection $=1-4$; indifference $=5$; acceptance $=6-9$ ) and purchase intent (rejection $=1$ and 2 ; indifference $=3$; acceptance $=4$ and 5 ) assigned by consumers of the dairy beverages: C (without addition of $L$. paracasei), P (containing L. paracasei), PI (containing L. paracasei and inulin) and PO (containing L. paracasei and oligofructose).
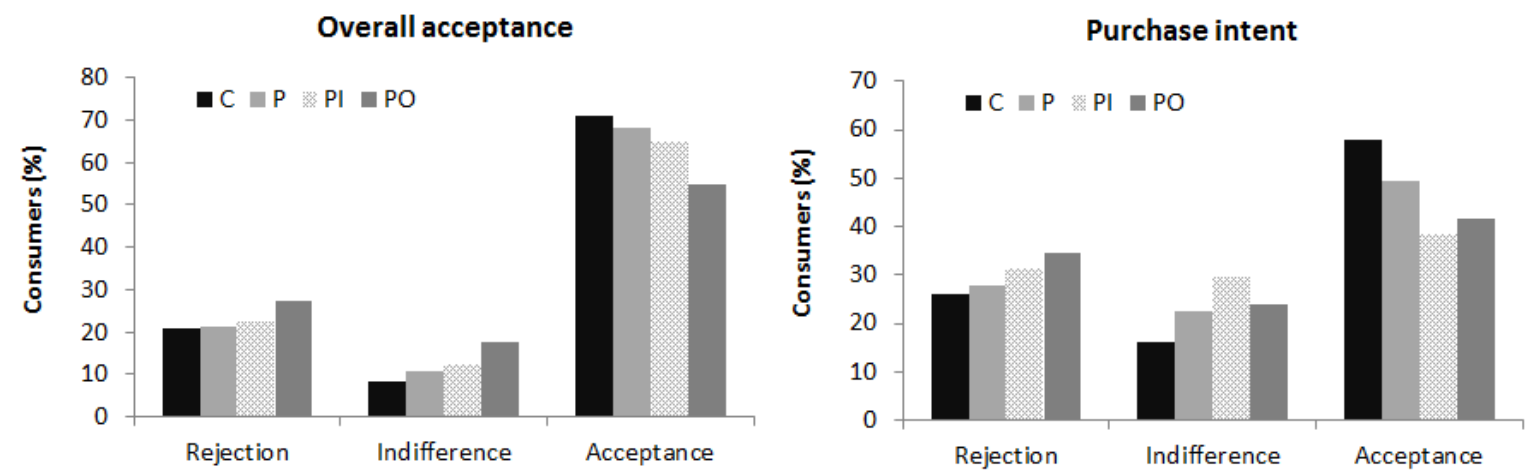

Source: Elaboration of the authors.

The sensory evaluation showed that the products were well accepted by consumers, as most of the scores were within the range indicating product acceptance (between "liked" and "liked very much"). Additionally, high purchase intent scores were found for all formulations. Further tests, including in vitro experiments, may be carried out to verify the protective effect of the food matrix on the survival of the L. paracasei strain subjected to simulated conditions of the human gastrointestinal tract as well as to evaluate the performance of the prebiotic ingredients inulin and oligofructose in these processes. 


\section{Acknowledgements}

The authors thank Danisco and Clariant for donating the probiotic microorganism L. paracasei and the prebiotic ingredients, respectively.

\section{References}

ALMEIDA K. E.; BONASSI, I. A.; ROÇA, R. O. Características físicas e químicas de bebidas lácteas fermentadas e preparadas com soro de queijo Minas frescal. Ciência e Tecnologia de Alimentos, Campinas, v. 21, n. 2, p. 187-192, 2001.

ANDREWS, W. H.; FLOWERS, R. S.; SILLIKER, J.; BAILEY, J. S. Salmonella. In: DOWNES, F. P.; ITO, K. (Ed.). Compedium of methods for the microbiological examination of foods. 4. ed. Washington: American Public Health Association, 2001. p. 357-380.

AGÊNCIA NACIONAL DE VIGILÂNCIA SANITÁRIA - ANVISA. Comissões tecnocientíficas de assessoramento em alimentos funcionais e novos alimentos. Alimentos com alegações de propriedades funcionais e ou de saúde, novos alimentos/ingredientes, substâncias bioativas e probióticos: lista das alegações aprovadas. Brasília: Editora Anvisa, 2005. Atualizado em julho/2008. Disponível em: <http://www.anvisa.gov. br/alimentos/comissoes/tecno_lista_alega.htm>. Acesso em: 20 set. 2011.

ASSOCIATION OF OFFICIAL AGRICULTURAL CHEMISTS - AOAC. Official methods of analysis. 15. ed. Washington: AOAC International, 1995.

AWAISHEH, S. S.; HADDADIN, M. S. Y.; ROBINSON, R. K. Incorporation of selected nutraceuticals and probiótico bacteria into a fermented milk. International Dairy Journal, Amsterdam, v. 15, n. 11, p. 1184-1190, 2005.

BONCZAR, G.; WSZOLEK, M.; SIUTA, A. The effects of certain factors on the properties of yoghurt made from ewe's milk. Food Chemistry, Davis, v. 79, n. 1, p. 85-91, 2002.

BRASIL. Ministério da Agricultura, Pecuária e Abastecimento. Secretaria de Defesa Agropecuária. Portaria n. ${ }^{\circ} 71$, de 21 de setembro de 2004. Regulamento da Agricultura e do Abastecimento, Regulamento técnico de identidade e qualidade de bebidas lácteas. Diário Oficial [da] República Federativa do Brasil, Brasília, 23 set. 2004.

BURITI, F. C. A.; CARDARELLI, H. R.; FILISETTI, T. M. C. C.; SAAD, S. M. I. Synbiotic potential of fresh cream cheese supplemented with inulin and Lactobacillus paracasei in co-culture with Streptococcus thermophilus. Food Chemistry, Davis, v. 104, n. 4 p. 1605-1610, 2007.

CASTRO, W. F.; CRUZ, A. G.; BISINOTTO, M. S.; GUERREIRO, L. M. R.; FARIA, J. A. F.; BOLINI, H. M. A. R. L.; CUNHA, R. L.; DELIZA, R. Development of probiotic dairy beverages: rheological properties and application of mathematical models in sensory evaluation. Journal of Dairy Science, Champaign, v. 96, n. 1, p. 16-25, $2013 \mathrm{a}$.

CASTRO, W. F.; CRUZ, A. G.; RODRIGUES, D.; GHISELLI, G.; OLIVEIRA, C. A. F.; FARIA, J. A. F.; GODOY, H. T. Effects of different whey concentrations on physicochemical characteristics and viable counts of starter bacteria in dairy beverage supplemented with probiotics Journal of Dairy Science, Champaign, v. 96, n. 1, p. 96-100, 2013b.

CHAMPAGNE, C. P.; GARDNER, N. J.; ROY, D. Challenges in the addition of probiotic cultures to foods. Critical Review on Food Science and Nutrition, London, v. 45, n. 1, p. 61-84, 2005.

CRUZ, A. G.; CAVALCANTI, R. N.; GUERREIRO, L. M. R.; SANT'ANA, A. S.; NOGUEIRA, L. C.; OLIVEIRA, C. A. F.; DELIZA, R.; CUNHA, R. L.; FARIA, J. A. F.; BOLINI, H. M. A. Developing a prebiotic yogurt: rheological, physico-chemical and microbiological aspects and adequacy of survival analysis methodology. Journal of Food Engineering, Essex, v. 114, n. 3, p. 323-330, 2013.

CUNHA, M. M.; CASTRO, F. P. C.; BARRETO, P. L. M.; BENEDET, H. D.; PRUDÊNCIO, E. S. Avaliação físico-química, microbiológica e reológica de bebida láctea e leite fermentado adicionados de probióticos. Semina: Ciências Agrárias, Londrina, v. 29, n. 1, p. 103116, 2008.

DRGALIĆ, I.; TRATNIK, L.; BOŽANIĆ, R. Growth and survival of probiotic bacteria in reconstituted whey. Le Lait: Dairy Science and Technology, Champaign, v. 85, n. 3, p. 171-79, 2005.

EL-GAWAD, I. A. A.; EL-SAYED, E. M.; HAFEZ, S. A.; ELZEINI, H. M.; SALEH, F. A. The hypocholesterolaemic effect of milk yoghurt and soy-yoghurt containing bifidobacteria in rats fed on a cholesterol-enriched diet. International Dairy Journal, Amsterdam, v. 15, n. 1, p. 37-44, 2005.

FARNSWORTH, J. P.; LIA, J.; HENDRICKS, G. M.; GUO, M. R. Effects of transglutaminase treatment on functional properties and probiotic culture survivability of goat milk yogurt. Small Ruminant Research, Bloemfontein, v. 65, n. 1-2, p. 113-121, 2006. 
FOOD AND AGRICULTURE ORGANIZATION OF THE UNITED NATIONS; WORLD HEALTH ORGANIZATION - FAO. Evaluation of health and nutritional properties of probiotics in food including powder milk with live lactic acid bacteria. Córdoba: Report of a Joint FAO/WHO Expert Consultation, 2001. 34 p. Available at: <ftp://ftp.fao.org/es/esn/food/ probioreport_en.pdf $>$. Accessed at: 03 fev. 2005.

FOX, P. F.; GUINEE, T. P.; COGAN, T. M.; MCSWEENEY, P. L. H. Fundamentals of cheese science. Gaithersburg: Aspen, 2000. 587 p.

FOX, P. F.; MCSWEENEY, P. L. H. Dairy chemistry and biochemistry. London: Blackie Academic \& Professional, 1998. $478 \mathrm{p}$.

GIBSON, G. R.; ROBERFROID, M. B. Dietary modulation of the human colonic microbiota: introducing the concept of prebiotics. Journal of Nutrition, Bethesda, v. 125, n. 6 , p. 1401-1412, 1995.

GOMES, A. M. P.; MALCATA, F. X. Bifidobacterium spp. and Lactobacillus acidophilus: biological, biochemical, technological and therapeutical properties relevant for use as probiotics. Trends in Food Science \& Technology, Norwich, v. 10, n. 4-5, p. 139-157, 1999.

GÜLER-AKIN, M. B.; AKIN, M. S. Effects of cysteine and different incubation temperatures on the microflora, chemical composition and sensory characteristics of bioyogurt made from goat's milk. Food Chemistry, Davis, v. 100, n. 2, p. 788-93, 2007.

GURGEL, M. S. C. C. A.; OLIVEIRA, A. J. Avaliação das características físico-químicas do iogurte. Leite \& Derivados, São Paulo, v. 4, n. 22, p. 38-43, 1995.

HAULY, M. C. O.; MOSCATTO, J. A. Inulina e oligofrutoses: uma revisão sobre propriedades funcionais, efeito prebiótico e importância na indústria de alimentos. Semina: Ciências Exatas e Tecnológicas, Londrina, v. 23, n. 1, p. 105-118, 2002.

HOLZAPFEL, W.; SCHILLINGER, U. Introduction to pre - and probiotics. Food Research International, Barking, v. 35, n. 2-3, p. 109-116, 2002.

HUGUNIN, A. O uso de produtos de soro em iogurte e produtos lácteos fermentados. Leite \& Derivados, São Paulo, v. 5, n. 43, p. 22-33, 1999.

INSTITUTO ADOLFO LUTZ - IAL. Métodos químicos e físicos para análise de alimentos. 4. ed. Brasília: Ministério da Saúde, 2005. 1020 p.
ISIK, U.; BOYACIOGLU, D.; CAPANOGLU, E.; ERDIL, D. N. Frozen yogurt with added inulin and isomalt. Journal of Dairy Science, Champaign, v. 94, n. 4, p. 1647-1656, 2011.

KESSLER, H. G. Food engineering and dairy technology. Copenhagen: Technical Dairy Publishing House, 1981. $654 \mathrm{p}$.

KOLIDA, S.; TUOHY, K.; GIBSON, G. R. Prebiotic effects of inulin and oligofructose. British Journal of Nutrition, London, v. 87, p. S193-S197, 2002. Supplement 2.

KOMATSU, T. R.; BURITI, F. C. A.; SAAD, S. M. I. Inovação, persistência e criatividade superando barreiras no desenvolvimento de alimentos probióticos. Revista Brasileira de Ciências Farmacêuticas, São Paulo, v. 44, n. 3, p. 329-347, jul./set. 2008.

KRÜGER， R.; KEMPKA，A. P.; OLIVEIRA， D.; VALDUGA, E.; CANSIAN, R. L.; TREICHEL, H.; DI LUCCIO, M. Desenvolvimento de uma bebida láctea probiótica utilizando como substratos soro de leite e extrato hidrossolúvel de soja. Alimentos e Nutrição, Araraquara, v. 19, n. 1, p. 43-53, 2008.

MAITY, T. K.; KUMAR, R.; MISRA, A. K. Development of healthy whey drink with Lactobacillus rhamnosus, Bifidobacterium bifidum and Propionibacterium freudenreichii subsp shermanii. Mljekarstvo, Zagreb, v. 58, n. 4, p. 315-325, 2008.

MEILGAARD, M.; CIVILLE, G. V.; CARR, B. T. Sensory evaluation techniques. Boca Raton: CRC, 1999. $387 \mathrm{p}$.

MONTGOMERY, D. C. Design and analysis of experiments. New York: John Wiley \& Sons, 2000. 684 p.

OLIVEIRA, M. N.; SIVIERI, K.; ALEGRO, J. H. A.; SAAD, S. M. I. Aspectos tecnológicos de alimentos funcionais contendo probióticos. Revista Brasileira de Ciências Farmacêuticas, São Paulo, v. 38, n. 1, p. 1-21, 2002.

ÖZER, B. H.; KIRMACI, H. Functional milks and dairy beverages. International Journal of Dairy Technology, Huntingdon, v. 63, n. 1, p. 1-15, 2010.

PAVUNC, A. L.; TURK, J.; KOS, B.; BEGANOVIC, J.; FRECE, J.; MAHNET, S.; KIRIN, S.; SUSKOVIC, J. Production of fermented probiotic beverage from milk permeate enriched with whey retentate and identification of present lactic acid bacteria. Mljekarstvo, Zagreb, v. 59, n. 1, p. 11-19, 2009. 
PIMENTEL, T. C.; GARCIA, S.; PRUDÊNCIO, S. H. Iogurte probiótico com frutanos tipo inulina de diferentes graus de polimerização: características físico-químicas e microbiológicas e estabilidade ao armazenamento. Semina: Ciências Agrárias, Londrina, v. 33, n. 3, p. 1059-1070, 2012b.

Effect of long-chain inulin on the texture profile and survival of Lactobacillus paracasei ssp. paracasei in set yoghurts during refrigerated storage. International Journal of Dairy Technology, Huntingdon, v. 65, n. 1, p. 104-110, 2012a.

PINTO, M. G. V.; FRANZ, C. M. A. P.; SCHILLINGER, U.; HOLZAPFEL, W. H. Lactobacillus spp. with in vitro probiotic properties from human faeces and traditional fermented products. International Journal of Food Microbiology, Amsterdam, v. 109, n. 3, p. 205-214, 2006.

ROBERFROID, M. B. Inulin-type fructans: functional food ingredients. Journal of Nutrition, Bethesda, v. 137, n. 1, p. 2493S-2502S, 2007.

Prebiotcs: preferential substrates for specific germs? American Journal of Clinical Nutrition, Bethesda, v. 73, p. 406S-409S, 2001. Supplement 2.

ROY, D. Technological aspects related to the use of bifidobacteria in dairy products. Lait, Les Ulis, v. 85, n. 1/2, p. 39-56, 2005.

RYBKA, S.; FLEET, G. H. Populations of Lactobacillus delbrueckii spp. bulgaricus, Streptococcus thermophilus, Lactobacillus acidophilus and Bifidobacterium species in Australian yoghurts. Food Australia, Sydney, v. 49, n. 10, p. 471-475, 1997.

SANDERS, M. E. Probiotics: considerations for human health. Nutrition Reviews, Bethesda, v. 61, n. 3, p. 91-99, 2003.

SCHALL, R. Estimation in generalized linear models with random effects. Biometrika, Oxford, v. 78, n. 4, p. 719-727, 1991.

SCHOLZ-AHRENS, K. E.; ADE, P.; MARTEN, B.; WEBER, P.; TIMM, W.; ASIL, Y.; GLÜER, C. C.; SCHREZENMEIR, J. Prebiotics, probiotics, and synbiotics affect mineral absorption, bone mineral content, and bone structure. The Journal of Nutrition, Bethesda, v. 137, p. 838S-846S, 2007. Supplement 2.

SHAH, N. P.; LANKAPUTHRA, W. E. V.; BRITZ, M. L.; KYLE, W. S. A. Survival of Lactobacillus acidophilus and Bifibobacterium bifidum in commercial yoghurt during refrigerated storage. International Dairy Journal, Amsterdam, v. 5, n. 5, p. 515-521, 1995.
SILVA, M. R.; FERREIRA, C. L. L. F.; COSTA, N. M. B.; MAGALHÃES, J. Elaboração e avaliação de uma bebida láctea fermentada à base de soro de leite fortificada com ferro. Revista do Instituto de Laticínios Cândido Tostes, Juiz de Fora, v. 56, n. 3, p. 7-14, 2001.

SIVIERI, K.; OLIVEIRA, M. N. Avaliação de vidade-prateleira de bebidas lácteas preparadas com "fat replacers" (litesse e Dairy-lo). Ciência e Tecnologia de Alimentos, Campinas, v. 22, n. 1, p. 24-31, 2002.

THAMER, K. G.; PENNA, A. L. B. Efeito do teor de soro, açúcar e de frutooligossacarídeos sobre a população de bactérias lácticas probióticas em bebidas fermentadas. Revista Brasileira de Ciências Farmacêuticas, São Paulo, v. 41, n. 3, p. 393-400, 2005.

Caracterização de bebidas lácteas funcionais fermentadas por probióticos e acrescidas de prebiótico. Ciência e Tecnologia de Alimentos, Campinas, v. 26, n. 3, p. 589-95, 2006.

THAMMARUTWASIK, P.; HONGPATTARAKERE, T.; CHANTACHUM, S.; KIJROONGROJANA, K.; ITHARAT, A.; REANMONGKOL, W.; TEWTRAKUL, S.; OORAIKUL, B. Prebiotics - a review. Songklanakarin Journal of Science and Technology, Hat Yai, v. 31, n. 4, p. 401-408, 2009.

VINDEROLA, C. G.; REINHEIMER, J. A. Enumeration of $L$. case $i$ in the presence of L. acidophilus, bifidobacteria and lactic starter bacteria in fermented dairy products. International Dairy Journal, Amsterdam, v. 10, n. 4, p. 271-275, 2000.

WANG, Y. Prebiotics: present and future in food science and technology. Food Research International, Ottawa, v. 42, n. 1, p. 8-12, 2009.

YAZICI, F., AKGUN, A. Effect of some protein based fat replacers on physical, chemical, textural, and sensory properties of strained yoghurt. Journal of Food Engineering, Essex, v. 62, n. 3, p. 245-254, 2004.

ZISU, B.; SHAH, N. P. Effects of $\mathrm{pH}$, temperature, supplementation with whey protein concentrate, and adjunct cultures on the production of exopolysaccharides by Streptococcus thermophilus 1275. Journal of Dairy Science, Champaign, v. 86, n. 11, p. 3405-3415, 2003. 
